\title{
QUEEN'S
UNIVERSITY
BELFAST
}

\section{Irish language education and the national ideal: The dynamics of nationalism in Northern Ireland}

McManus, C. (2016). Irish language education and the national ideal: The dynamics of nationalism in Northern Ireland. Nations and Nationalism, 22(1), 42-62. https://doi.org/10.1111/nana.12142

Published in:

Nations and Nationalism

Document Version:

Peer reviewed version

Queen's University Belfast - Research Portal:

Link to publication record in Queen's University Belfast Research Portal

\section{Publisher rights}

(c) 2015 The Author

This is the peer reviewed version of the following article: McManus, C. (2015), Irish language education and the national ideal: the dynamics of nationalism in Northern Ireland. Nations and Nationalism, which has been published in final form at doi:10.1111/nana.12142, Irish language education and the national ideal: the dynamics of nationalism in Northern Ireland. Nations and Nationalism. This article may be used for non-commercial purposes in accordance with Wiley Terms and Conditions for Self-Archiving

\section{General rights}

Copyright for the publications made accessible via the Queen's University Belfast Research Portal is retained by the author(s) and / or other copyright owners and it is a condition of accessing these publications that users recognise and abide by the legal requirements associated with these rights.

\section{Take down policy}

The Research Portal is Queen's institutional repository that provides access to Queen's research output. Every effort has been made to ensure that content in the Research Portal does not infringe any person's rights, or applicable UK laws. If you discover content in the Research Portal that you believe breaches copyright or violates any law, please contact openaccess@qub.ac.uk. 


\section{Irish Language Education and the National Ideal: The Dynamics of Irish Nationalism in Northern Ireland.}

Since the late 1960s nationalism has been identified as a dominant force in the political culture of Northern Ireland and the identification of an Irish nationalism, in particular, has been interpreted as the continuation of a historical demand for national independence for the entire island (Boyce 1995; English 2006; Phoenix 1994). Recent studies have suggested, however, that the 'Irish Nationalist' population in Northern Ireland has become increasingly content within the new political framework established by the various peace agreements negotiated since 1998 and have developed a sense of belonging to the Northern state (Hayward, et al., 2014). Any such heightened attachment to Northern Ireland raises important questions about the nature of Irish nationalist politics and especially, about how the wider population came to relate to the national aspirations of Sinn Féin which has become the largest party representing Irish nationalism over the past decade.

In placing the Northern Ireland situation within the theoretical framework of nationalism, this paper will examine the nature of 'Irish nationalism' since the 1960s and explore how the political ideals espoused by Sinn Féin reflect the priorities of the population they claim to represent. To do so the paper will focus on two characteristics often highlighted within academic literature as being important in helping to shape and define national identity and cohesion; national language and education (Edwards, 2009; Green, 1990; Kamusella, 2012).

Through an analysis of Irish language study in Northern Ireland's schools it will be argued that it is possible to gain a better understanding of the dynamics that have helped to influence modern Irish nationalism. It will be contended that the relationship between nationalist ideology and the 'nationalist community' is much more complex than is often allowed for 
and, in particular, that educational inequalities have contributed to an uneven development of nationalism within that community.

\section{The 'Imagined Community'?: Nations and Nationalism in theory}

There is no disagreement that nationalism has been 'around' on the face of the globe for, at the very least, two centuries. Long enough, one might think, for it to be reliably and generally understood. But it is hard to think of any political phenomenon which remains so puzzling and about which there is less analytic consensus (Anderson, 2012 [1996]: 1).

The concept of nationalism has provoked considerable academic debate over the past half century but with a particular growth of interest since the 1980s (Anderson, 1991; Billig, 1995; Gellner, 2006; Smith, 2009). A prominent theme within these discussions centres on the factors contributing to the development of nationalist sentiment. In particular, there has been much debate as to whether nationalism invents nations (Gellner, 2006; Hobsbawm, 1992; Anderson, 1991), or whether the existence of a common, ethnic identity, shapes nationalism (Armstrong, 1982; Smith, 2009; 2008; Hutchinson, 2005).

For scholars such as Ernest Gellner (1964; 2006), Benedict Anderson (1991) and Eric Hobsbawm (1992), the conditions that enabled the growth of a nationalist vision simply did not 'exist before the advent of modernity' (Smith, 2008: 3) as the tools necessary to create the required sense of shared belonging did not exist (Hobsbawm, 1992, p. 10). The social and technological advances associated with modernity provided the conditions to advance nationalist thinking and, as such, it was nationalism that created nations rather than the other way round (Gellner, 2006: 47; Hobsbawm, 1992: 10).

This 'modernist' analysis has been disputed by prominent scholars such as John Armstrong (1982), Anthony D. Smith (Smith, 2009; 2008) and John Hutchinson (Hutchinson, 2005) who 
argue that the power of nationalism cannot be explained merely by the 'imaginings' of an elite group of nationalists. Smith (2009) argues that 'ethnic identities and communities' are crucial elements in 'the formation and persistence of nations' (p. 21) and puts forward the argument that there is a need to understand the 'inner world' of both 'ethnicity and nationalism' through 'an analysis of symbolic elements and subjective dimensions' (p. 23). For Smith, the cultural elements of 'symbol, myth, memory, value, ritual and tradition' hold the key to our understanding better concepts such as 'ethnicity, nations and nationalisms' as they help to endow a community with a 'distinctive symbolic repertoire in terms of language, religion, customs and institutions' which helps to differentiate the nation from 'other analogous communities'. A detailed analysis of such, he argues, is crucially lacking from the modernist critique which fails to appreciate the important role played by "ethnic communities', or 'ethnies', in helping to define the nature of nations and nationalism in the modern era. These 'ethnies' he defines as 'a named and self-defined human community whose members possess a myth of common ancestry, shared memories, one or more elements of common culture, including a link with a territory, and a measure of solidarity, at least among the upper strata' (p. 27).

For ethno-symbolists it is to these 'ethnies' that nationalists turn in order to develop their vision of the nation as they provide it with 'real resonance' amongst the wider populace (Hutchinson, 2005, p. 37). At the same time, however, Hutchinson also recognises that there are very often competing interpretations about the past and, as such, there is an element of 'imagining' required, by a nationalist elite, in order to choose those characteristics of the nation that engender greatest unity. In his analysis of the growth of Paris as a symbol of the French nation, for example, he points out that its status was enhanced by the revolution - in spite of the Gironde desire for decentralisation - as a result of an older ethnic tradition that had helped to develop a 'sacred aura' around the city: 
The sacred energies associated with kingship were transferred to the republic, for which Paris now became the creative centre of modernity and change. Paris was the training centre of state elites and Parisian functionaries, like earlier royal intendants, were sent to the departments to enforce the revolution in the localities (p. 39).

Whilst the historically important status of Paris was protected in the new France there was also a need for some reinvention of the wider national character to reflect the city's identity thus there was the need to "make" Parisian language and culture the "bearers of the national civilising project' (p. 39). That there is the need for processes of 'revival' and 'redevelopment' (p. 41) raises important questions as to which elements are then chosen as symbols of the modern nation but also how they are then extended to the wider populace (Özkirimli, 2008; 2003; see also Hroch, 2000; Wodak, et al., 2009). For the purposes of this paper, two key aspects will be analysed in order to explore the processes that have become important aspects for discussion within the context of nationalism in Northern Ireland: the status of the 'national language' and, subsequently, the role of education in the nation building process. ${ }^{1}$

\section{Making the Nation - Language, Education and a Problematic Ideal}

Since the nineteenth century 'language' has come to play a central role in helping to define notions of national identity in Europe (Barbour \& Carmichael, 2000; Kamusella, 2012). So closely tied did language and political identity become, Kamusella (2012) argues, that 'it is impossible to speak in a knowledgeable manner' about the history of Central Europe 'without recounting the politics of language, which legitimized political and social changes proposed by national movements and their nation-states' (pp. 6-7). 
The linkage between language and nation-building emerged during the second half of the eighteenth century with German thinkers such as Johann Gottfried von Herder and Johann Gottlieb von Fichte identified as being important figures in helping to establish 'language as the essential defining characteristic of a nation' (Barbour, 2000: 15). That this should be so, of course, was not without its difficulties. Billig (1995) points out, when looking at the significance of the French Revolution to the historical development of nationalism, that the 'language in which the Declaration had been written was only spoken by a minority of the population as their first tongue' and that South of the Loire, 'it was generally incomprehensible' (p. 25). As such, the nation, and its unifying identity, was 'a project to be attained' (p. 25) that included a need to 'impose' a 'national language'. This helped to place the issue of education on the agenda of those nationalists seeking to 'revive' or 'redevelop' a sense of national identity (Green, 1990). The emergence of systems of national education in nineteenth century Europe is viewed as being of great importance to the growth of national feeling, with schools seen as a socialising tool capable of inculcating a sense of loyalty to the nation amongst the masses (Anderson, 1991; Green, 1990; Hobsbawm, 1992; Reisner, 1922; see also Gramsci, 2007).

Such an analysis, however, tends to ignore the great complexities associated with the growth of popular education during the nineteenth century, and, in particular, the often-conflicting roles that schools were required to perform (Green, 1990; Hjerm, 2001). Cannadine (2000), in his analysis of British society and the role of education, stresses that 'teaching, learning and literacy were intrinsically hierarchical' and the 'higher up the social scale, the better, the longer and the more expensive the education that was available' (p. 47).

Such educational inequalities, with the desire to protect an established social order, had the potential to conflict with the emerging nationalist ideal that sought to present 'the people' as the central component of the nation and as one, unified/homogeneous body (Gellner, 2006; 
Hroch, 2000). Although key aspects such as a national language could be 'imposed', this unifying dimension was often weakened by other social and cultural divisions that needed to be maintained (Cannadine, 2000; McCann, 1977; Thompson, 2013). This, indeed, was reinforced by the varying content of the education deemed appropriate for the differing social classes wherein the upper tiers received a classical or professional education whilst the priority for the lower orders was largely vocational (Goldstrum, 1977; Green, 1990). This inevitably meant that those within the emerging working class communities did not study the 'national' subjects, such as history, to the same extent as their middle and upper class counterparts with the consequence being that their sense of 'national identity' was often less developed.

The relationship between academic achievement and the inculcation of nationalist sentiment in Europe has not been static over the past century. Changing policy priorities across the continent since the late 1970s have had a significant impact on education with a much greater focus now being placed on both the idea of global citizenship (Keating, 2009) and, more specifically, its 'ensuring economic productivity and competiveness in the context of 'informational capitalism"' (Ball, 2008, p. 1). Such new priorities have seemingly contributed to a changed dynamic between academic success and nationalist ideology with the latter now, increasingly, undermined by the former (Coenders \& Scheepers, 2003; Hjerm, 2001). Hjerm (2001) explains this by arguing that increased levels of education 'in some sense prevents people from internalising the nationalistic belief system' (47-8) because they become more aware of the 'imagined' dimension of nation formation. Whilst this is unquestionably true, it needs to be considered within the context that higher education did not have a similar impact for previous generations. Rather, the explanation lies with the emergence of a new scholarly approach to the study of history that is, in itself, less nationalistic in orientation and increasingly willing to challenge established narratives by questioning, not only the origins of 
the nation, but also the myths and symbols that had helped to define particular ideas of national identity (Lawrence, 2005). Developing and promoting such a scholarly approach was, however, more difficult in countries where nationalism continued to influence the political culture (O'Mahony \& Delanty, 2001).

\section{The Development of Irish Nationalism}

The issues and developments analysed above have helped to shape the nature of Irish nationalism as it has evolved since the nineteenth century. Barbour (2000) has argued that as language became a crucial component of nationalist ideology in Europe it helped to introduce a 'linguistic element into national movements, Irish nationalism being a good case, which had previously placed little stress on such questions' (p. 15). This influence can be seen as early as 1843 in the writings of Thomas Davis, a leading figure in the Young Ireland movement, who declared that a 'people without a language of its own is only half a nation'. He further contended that each nation should 'guard its language more than its territories -'tis a surer barrier, and more important frontier, than fortress or river'. ${ }^{2}$ This became an increasingly influential political mode of thought during the late nineteenth century with the emergence of various groupings espousing a more culturally based nationalism with the language at its heart (Billig, 1995; Hutchinson, 1987; McMahon, 2008). The fact that Ireland was seen to possess its own distinctive cultural identity, including its own language, was seen to give greater legitimacy to claims for nationhood - a nationhood that, increasingly, was deserving of political independence (Boyce, 1995; Crowley, 2008).

The major problem faced by these 'cultural nationalists', and those whose political nationalism stemmed in part from the cultural arguments, was that Irish language usage had experienced a sharp decline during the nineteenth century so that by 1911 the number of Irish 
speakers stood at 582,446 , representing 13.3 per cent of the total population. Perhaps even more significantly, only 16,873 of these were Irish monoglots (Crowley, 2008: 158).

Given the increasingly influential view that the language formed the basis for Ireland's claim to nationality it was vital that action be taken to not only protect Irish but re-establish its position as the vernacular of the people - a process that required revivalists to confront the commonly held view that the language was 'backward' and an obstacle to Ireland's social and economic development (Crowley, 2008). As such, education became a key battle-ground in the wider 'national struggle' of the period. Organisations such as the Gaelic League were established to actively teach the language within communities but also to lobby on its behalf for a greater status within the national schools system (Lyons, 1985). These priorities were reinforced with the establishment of the new Irish Free State in 1922 as efforts were made to develop a sense of Irish national identity that was seen to be in some way akin to that espoused by the leaders of the symbolic 1916 Rising and which would help build upon the limited political independence secured in the 1921 Treaty (See Collins, 1996; also Lougheed, 2012; O'Callaghan, 2009).

Education, therefore, became a central tool in the early efforts to restore Irish as the language of the populace (Farren, 1995; Kelly, 2002). For many of the leading revivalists, who either continued to exert a considerable influence on government policy or who themselves became part of the new post-independence governments, schools were seen as an obvious and quick mechanism for 'Gaelicising' the young (Brown, 2004; Farren, 1995). That they failed in this task has subsequently been blamed on the mistaken nationalist analysis that the national schools system, introduced by Britain from the 1830s, had been the primary cause of Irish language decline and that a new language education policy could, on its own, undo the damage (Crowley, 2008, pp. 165-66). There was a strong agreement within government for the views expressed by the influential cultural nationalist Fr. Timothy Corcoran that schools 
could restore the language 'even without positive aid from the home' and a flawed assumption that young people would simply start to use the language beyond the classroom despite there being little or no social or economic infrastructure to support this (Crowley, 2008: 166).

A further important consideration in relation to schooling centres on the nature of the educational system itself and how this had the potential to impact, not only the failure of the revival project but also the nature of nationalist sentiment in the decades following independence. Although the school curriculum was subject to significant reform in the decade after independence (Atkinson, 1969; Farren, 1995; O'Callaghan, 2009) little else about the system changed. Brown (2004) describes how the 'twenties saw...very little change in the Irish educational system' which, consequently, meant that it retained:

...its class-conscious, religiously managed secondary school, its technical sphere generally thought socially inferior to the more academic institutions, and its universities almost the sole preserve of students from propertied or professional backgrounds (p. 39).

Although the primary schools placed a significant emphasis on the teaching of Irish the further a child progressed academically the more they studied the language and, indeed, the more important the language became. This was due to the fact that from 1925 a pass in Irish at Intermediate level (aged 15-16) was made compulsory for overall academic success and also because of legislation that made admission into particular careers in the public services dependent on knowledge of the language (Crowley, 2008, pp. 168-71). Importantly, progression into intermediate education was, as Crowley (2008) highlights, very much reserved to the few with only around 5 five per cent of the age group progressing into secondary education during the early 1920s (p. 168). Brown (2004) points out that by the 
1960s little had changed with a 1962 report entitled Investment in Education, produced by a government appointed commission, highlighting a continuing 'association between class and educational advancement'. Moreover, this became ever 'more marked the higher the age group and the higher level' (Brown, 2004, pp. 237-39).

Such educational failings suggest that the Irish language - supposedly a primary component of the 'national identity' - could have become unevenly developed across the population dependent on academic achivement. Brown, for example, observes that 'Gaelic enthusiasm' ${ }^{3}$ was 'evident among some well-educated adults in the English-speaking areas' and that 'when broken down by occupations the professional class boasted the largest percentage of Irish-speakers - 43.5 percent of this group claiming knowledge of the language' (2004: 51). If particular concepts of Irish national identity, based on the definitions of a nationalist elite, are stenghtened by academic progress within a 'Gaelicised' educational system, it does raise questions concerning how nationalism takes shape in the large sections of the population who left school at the age of fourteen.

\section{Language and Education in Northern Ireland - A Complex Picture}

The idea that educational inequalities can affect the nature of national sentiment is of importance when examining the conditions in Northern Ireland that allowed for the outbreak of violence often associated with increased nationalist sentiment during the late 1960s and early 1970s.

It is necessary to contextualise the violence of the period, and particularly its roots, in confrontations arising from a campaign for civil rights that sought equality for the Catholic population within the state rather than the more traditional goal of Irish unity (Bew, 2009; Arthur \& Jeffery, 1988). Indeed, the civil rights campaign has been interpreted by some as representing a changed political dynamic in which the growing Catholic middle classes were 
becoming ever more reconciled to the realities of partition and more aware of the potential for socio-economic progression (Cochrane, 1999, pp. 18-22). This, it has been suggested, stemmed from a rising ambition within northern Catholics as the legacy of the 1947 Education Reform Act (NI) became manifest (Staunton, 2001). This Act had introduced the provision of free compulsory education up until the age of 15 , the raising of funding for Catholic maintained schools to $65 \%$ and the making available of grants for study at university. The first beneficiaries of these reforms emerged during the 1950s and 1960s with a desire to progress the social ladder, thus potentially undermining traditional nationalist politics (Arthur, 1974; Arthur \& Jeffery, 1988; Farren, 1995).

The reality, however, was more complex. There is little doubt that ambitions within the new, university-educated generation rose considerably but this did not necessarily mean an immediate weakening of traditional nationalist loyalties. Rather, it helped to create a measure of conflict between the two as the young people struggled with a continued attachment to the nationalist ideal of Irish unity and a desire to advance the social ladder. The nature of this conflict is evident in an Irish Times piece written by John Hume in 1964 describing the new scenario:

The crux of the matter for the younger generation is the continued existence, particularly among the Catholic community, of great social problems of housing, unemployment and emigration. It is the struggle for priority in their minds between such problems and the ideal of an United Ireland with which they have been bred that had produced the frustration...It may be that the present generation of younger Catholics in the North are more materialistic than their fathers but there is little doubt that their thinking is principally geared towards the solution of social and economic problems. This had led to a deep questioning of traditional Nationalist attitudes. ${ }^{4}$ 
Although there was this 'questioning of traditional Nationalist attitudes' it was not something that could be easily cast aside. As Hume acknowledges, young people continued to be brought up believing in the 'ideal of an United Ireland'. Importantly, this was not just a political socialisation established in the home. There is evidence to suggest that those young people attending Catholic grammar schools, in particular, continued to gain a 'nationally' based education that, like schools in the South, placed an emphasis on a study of the Irish language, Irish history and the playing of Gaelic games (McGrath, 2000). This had been a characteristic of Catholic education in Northern Ireland since partition and was often a source of tension between the managers of the Catholic schools and the Stormont government during the 1950s (McGrath, 2000; Farren, 1995). The impact of this, as we enter the era of the civil rights movement when nationalist sentiment within the Catholic community was supposed to be waning, can be seen from the number of students studying the Irish language at ' $\mathrm{O}$ ' Level $^{5}$

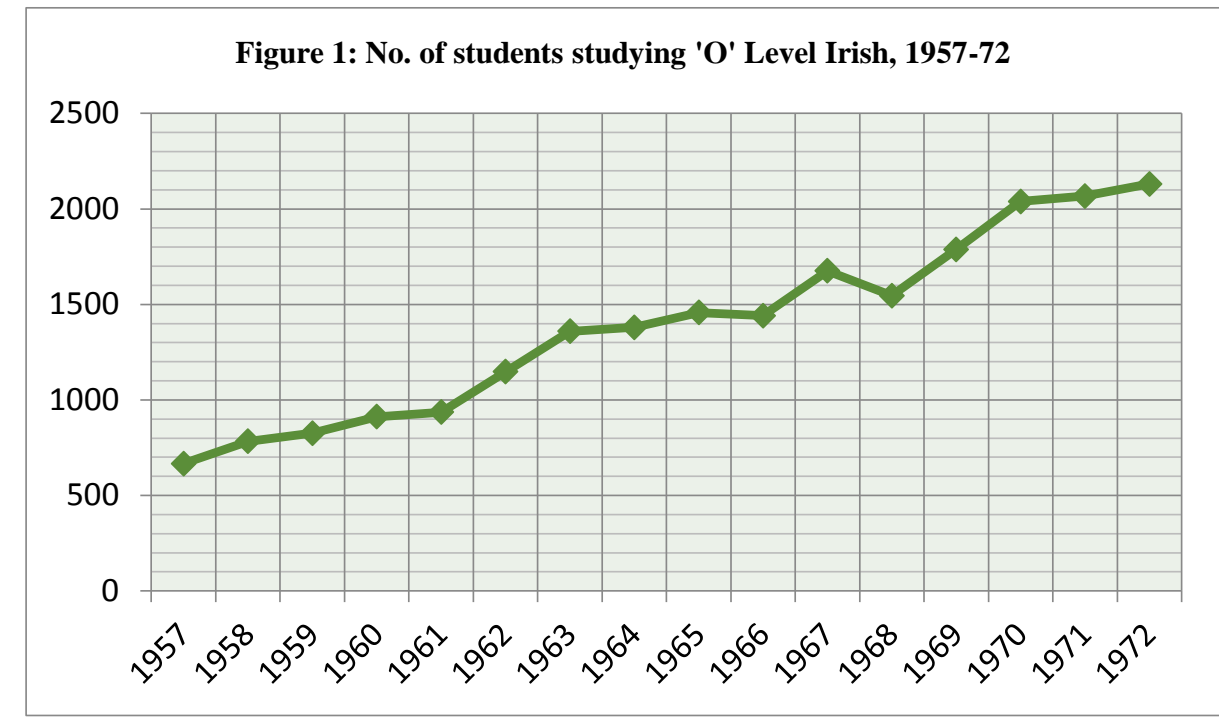
which shows a considerable rise from 667 students in 1957 to 2,131 by 1972 (Figure 1).

Accounts from the period help to

contextualise this growth and also, crucially, highlight some of the political connotations attached to it. In an account of her educational experiences during the 1950s, Bernadette Devlin (1969), who would later become a civil rights campaigner and Member of Parliament, describes her grammar school as being 'a militantly Republican school' and puts this down to the vice-principal, for whom: 
...everything English was bad. She hated the English - and with good reason...Everything we did in school was Irish-orientated. She was a fanatic about Irish culture... (pp. 61-2).

The Irish language formed an important part of this fanaticism as Devlin highlights:

I knew no Irish when I went to Grammar school, but the class I joined was a class of crude political rebels: we knew nothing about politics except what we were for and against, and we were for Ireland and Mother Benignus was our heroine. In addition to our passion for Ireland we had a very good teacher of Gaelic, with an enthusiastic approach to the subject, so that by the end of my first year the whole class was way above the standard of Irish-speaking expected of eleven-year-olds (p. 63).

That the school was seen to develop political thinking and link this to the cultural subjects being studied highlights the extent to which some schools were still very much responsible for promulgating a traditional nationalist sentiment (McGrath, 2000). It is important to recognise, however, that this political socialisation was not spread evenly across the Catholic community. In the first instance, there remained a significant problem when it came to the provision of secondary education for the Catholic population with McGrath (2000) pointing out that by $1957 / 58$ it was still the case that 'the overwhelming majority of Northern Ireland's voluntary primary school graduates were not enjoying a secondary education' (p. 144). ${ }^{6}$ He further notes that by the end of the 1950 s a 'Protestant primary school graduate was twice as likely as his or her Catholic counterpart to be attending a secondary school' (p. 144).

This lack of educational provision was not the only factor determining inequality when it came to the dissemination of nationalistic beliefs in schools. A second, and perhaps more 
important cause in the longer-term, was the nature of the schooling itself. This centred on the fact that the form of cultural education, highlighted above, was much stronger in Catholic Grammar Schools than it was in Catholic Secondary Schools where the emphasis tended to be more vocationally driven. As a consequence of this the more academic, and crucially, 'national' subjects, tended to be given a lesser status. This was certainly the case when it came to studying the Irish language. Data for the 1970s, although showing a rise in the number of young people studying the language at Certificate of Secondary Education level, reinforces the fact that it was, primarily, a subject studied at the more academic ' $O$ ' Level offered in the Grammar Schools (Table 1).

\begin{tabular}{|c|c|c|}
\hline Year & GCE 'O' Level & $\begin{array}{c}\text { Certificate for } \\
\text { Secondary Education }\end{array}$ \\
\hline 1973 & 1949 & 51 \\
\hline 1974 & 1702 & 87 \\
\hline 1975 & 1783 & 135 \\
\hline 1976 & 1743 & 201 \\
\hline 1977 & 1754 & 163 \\
\hline 1978 & 1753 & 123 \\
\hline
\end{tabular}

It must be acknowledged that these statistics do not present a complete picture as there will inevitably be some crossover between the Secondary and Grammar schools. Moreover, the

Table 1: Number of students studying ' $O$ ' Level and CSE Irish Secondary schools would have language, 1973-78

provided classes in Irish that were not necessarily translated into young people taking exams. Nevertheless, they do give some indication of the stark differences between the two sectors when it comes to the higher level study of Irish. This is very much reflected in the views expressed by some of those who came through the educational system and joined the ranks of the (re)emerging Irish Republican Army (IRA) during the late 1960s and early 1970s. One former IRA prisoner recalled how:

The Irish language used to be taught in the citadels - it would have been St Malachy's, St Mary's, the Cluain Ard, the Ard Scoill, you know, that's where the 
Irish language was; and the Irish language would not have been in working-class areas bar the former IRA prisoners homes from the $1940 \mathrm{~s}^{7}$

\section{Language, Nationalism and the Working Class}

That there was some level of detachment between the working-class Catholic community and the important cultural dimensions of Irish nationalism implies that notions of 'Irishness' remained unevenly spread and that nationalism often manifested itself in different ways. This has considerable implications for how we should interpret the nature of the Northern Ireland conflict and how it developed. This centres largely on the fact that when the IRA re-emerged during the late 1960s and early 1970s it was young people from the working class areas often those most likely not to have studied 'national' subjects such as Irish or Irish history that swelled its ranks (English, 2004; Taylor, 1998). As such, the traditional ideology of Irish nationalism and republicanism was not necessarily a driving motivation for new recruits of the movement but rather a communal sense of victimhood and wider feelings of hostility to the Unionist administration in Stormont shaped their political views. This can be seen from the comments of one IRA ex-prisoner who reflected that in the early years of the conflict the aspiration of the republican movement remained simple: 'Brits out of Ireland...that was the core of it'. ${ }^{8}$ Republican leaders recognised from an early stage, however, that this needed to change and that republicans, particularly active republicans, needed to be more aware of their wider social, political and cultural aspirations. The primary mechanism for bringing this about was through a significant programme of internal debates, discussions and classes held in the prisons from the 1970s. These debates, organised by the more politically minded figures, aimed to advance the political dimension of the republican struggle:

Now internally within republicanism you have had a debate which has been going on from that [Brits out] where it goes to socialism as one of the component parts: does nationalism come before it...or are they hand in hand ${ }^{9}$ 
One consequence of these educational activities was a return to the type of national ideals espoused during the 1916-21 period. Northern republicans became increasingly vocal in their criticism of the Southern state and claimed that parties such as Fianna Fáil and Fine Gael had abandoned the true principles of 1916. Arguing against the prominent status afforded to the Catholic Church in Southern politics and the willingness of political leaders to condemn IRA activities in the North, republican leaders claimed that the 'Free State' had wholly abandoned the ideals of historic figures such as Patrick Pearse and James Connolly whose spirit now lived on only in the emerging Provisional IRA (Adams, 1994; English, 2004). Such political arguments were seen, by republicans, to give greater legitimacy to the resurgent militarism that was based on the narrative of a historic 'armed struggle' that would bring independence to the island. The young men and women 'volunteers' swelling the ranks of the republican movement were, therefore, merely the latest in a long line willing to fight for Ireland (Adams, 1994).

As the political dimension increased in importance, so too did the status of the Irish language. The language, again, came to be seen as an important symbol of Irishness, and a further component of the historic republican struggle that had been abandoned by the southern state (Adams, 1994; O'Reilly, 1999). Within the republican wings of the Maze prison the language became both a tool against the prison regime but also, increasingly, an important link to previous nationalist campaigns. Irish language classes, taught by those prisoners with a knowledge of the language, became so common amongst Republican prisoners that the prisons themselves became known as a 'Jailtacht' (MacIonnrachtaigh, 2013). ${ }^{10}$

Upon their release from prison many republicans played a significant role in giving the language a more prominent status within what was seen as a wider political struggle against the effects of British colonialism on the island (Howe, 2000; O'Reilly, 1999; 1997). A Sinn 
Féin poster from the mid-1980s, for example, urged the populace to 'RESIST BRITISH

RULE: LEARN IRISH' ${ }^{11}$. It was also to the fore in a party publication, Learning Irish: A Discussion and Information Booklet (1985), which declared that:

Sinn Féin is pledged to resisting not only economic and political oppression but also the cultural and social controls imposed by the British and their allies on the Irish people (Sinn Féin, 1985, p. 2).

Furthermore, it stressed that:

...it is our contention that each individual who masters the learning of the Irish language has made an important personal contribution towards the reconquest of Ireland (Ibid).

This was reiterated the following year in a further publication entitled The Role of the Language in Ireland's Cultural Revival (1986), which sought to emphasise the importance of Irish to the wider 'struggle' and its role in fighting a wider Anglo-American 'Coca-Cola culture'. One contributor, Pádraig Ó Maolcraoibhe, stated his belief that:

In the six north-eastern counties of Ireland under British rule, nationalists are taking a greater interest in the Irish language revival than ever before. None can dispute the fact that this is connected with the political and military struggle that has been going on since the late sixties, which has heightened national consciousness among Northern Nationalists (1986, p. 7).

This was an aspect of the wider republican agenda that Gerry Adams, a leading figure within Sinn Féin throughout much of the period, was particularly keen to emphasise in his writings and policy statements (Feeney, 2002). In his 1994 book, Free Ireland: Towards a Lasting Peace, which sought to give a political context to the IRA violence of the previous twentyfive years, he maintained that: 
The revival of the Irish language as the badge of identity, as a component part of our culture and as the filter through which it is expressed, is a central aspect of the reconquest (Adams, 1994, p. 121).

To develop these ideals republicans worked to establish community based Irish language classes and Irish-medium schools that were kept very much separate from both the mainstream education system and the Catholic church. ${ }^{12}$ The language became ever more evident in nationalist, working-class, areas and in West Belfast the language became so prominent that it led to the formation of a 'Gaeltacht Quarter'. All of this helped to generate a large degree of optimism that progress was being made in the wider 'struggle' as can be seen in the writings of Ó Maolcraoibhe (Sinn Féin, 1986):

In the Irish schools in the North, working-class kids predominate for their parents were radical enough to break out of the system. The children are being given a direct link with the culture of their ancestors. They will grow up to lead a lot of their lives through Irish and they will not feel the alienation of Irish people with only the language imposed on them by imperialism in their mouths (p. 8).

It is important to note, however, that despite the heightened nationalist sentiment generated by the conflict and the wider political manoeuvrings on issues such as the Irish language, evidence would suggest that such a reawakening remained limited.

\section{Irish Language Education - A Limited Revival?}

There can be little doubt that the political climate in Northern Ireland during the years of conflict helped to generate a greater degree of national consciousness within the Catholic community and, perhaps more specifically, within sections of the Catholic working class population who had been mobilised by political leaders from within their own areas. How this raised national consciousness then manifested itself needs greater analysis however. In particular, there is a need to consider the challenge presented by Eric Hobsbawm (1992) to 
examine how the 'official ideologies' of nationalist movements come to be reflected in the communities that they claim to represent (p. 11). Having established the prominent place afforded to the Irish language within the 'official ideology' of Sinn Féin, for example, we would expect to see usage of the language increase significantly, particularly as the party increased its electoral standing throughout the 1990s and 2000s. An examination of educational statistics, however, presents a more complex picture that raises important questions concerning how a 'nationalist' community relates to the ideals of a nationalist movement in a modern, western democratic society.

As highlighted earlier there was a significant rise in the number of young people predominantly Catholics - studying the Irish language at 'O' Level between 1957 and 1972, when the figure reached 2,131 entrants. In the decade after 1972, despite the heightened political consciousness generated by the conflict and the prominent ideological status afforded to the language, there was a decline in the number of young people choosing to study Irish so that by 1982 there were 1,658 entrants: a fall of 473 from the 1972 figure. Perhaps even more significantly this decline was taking place within the context of a rising school population. Statistics provided by Sweeney (1988) for the period 1972-1986 (Table 2)

\begin{tabular}{|c|c|c|c|c|c|}
\hline & 1972 & 1977 & 1982 & 1986 & demonstrate \\
\hline Numbers studying Irish & 2,131 & 1,917 & 1,658 & 1,529 & extent to whi \\
\hline $\begin{array}{l}\text { Total number of } 15 \mathrm{yr} \text {. old } \\
\text { students in secondary } \\
\text { education }\end{array}$ & 16,735 & 25,678 & 27,717 & 27,734 & $\begin{array}{l}\text { Irish remained } \\
\text { little more than a }\end{array}$ \\
\hline $\begin{array}{l}\text { Proportion of students } \\
\text { studying Irish }\end{array}$ & $12.7 \%$ & $7.5 \%$ & $5.98 \%$ & $5.5 \%$ & minority subject \\
\hline
\end{tabular}

proportion of the total number of students, its study had fallen quite significantly.

It is important to point out that the numbers studying Irish were actually larger than these statistics would suggest given that the language was still a compulsory subject for the first 
three years of study within many Catholic secondary and grammar schools (McGrath, 2000). The actual numbers studying Irish at this lower level are difficult to identify but Prichard (1982) has suggested that the number was potentially as high as twenty-five thousand whilst Ó hAdhmaill (1989) has argued that in 1986 the figure stood at twenty thousand. What is important about the ' $\mathrm{O}$ ' Level/GCSE statistics presented above is that they provide data on the numbers choosing to study the language once the period of compulsion had ended. As such, they show that the vast majority of students stopped studying it as soon as this option became available, irrespective of its perceived symbolism - a symbolism often highlighted within the schools themselves (Kelly, 2002; McGrath, 2000).

Politically, the late 1980s and early 1990s represented a period of transition within Northern Ireland when various exploratory talks began about the potential for developing a peace process (Bew, 2009; Mallie \& McKittrick, 2002; Taylor, 1998). Although the IRA continued its armed campaign, we see a shifting narrative emerging within the Sinn Féin leadership that spoke of the potential for peace and a political strategy capable of furthering republican aspirations (Adams, 1994; Sinn Féin, 1987). The Irish language became a crucial component of this strategy and it came to act as an alternative ethno-symbol to the militarism that had largely dominated republicanism since the 1970s. Its importance was reflected in the status Sinn Féin afforded to it during the peace talks of the late 1990s when the party secured a British government commitment to 'take resolute action' for its promotion (HMSO, 1998).

This heightened political status and symbolism were contributing factors in helping to increase the numbers of young people studying the language at the new GCSE level. Numbers rose from 1,650 in 1989 to 2,021 by the $1995 / 96$ academic year and this rise continued until 2002/03 when numbers peaked at 2,689 GCSE entrants. One of the important characteristics of this growth is that, unlike the growth of the1960s, it centred predominantly 
on Catholic secondary schools. Indeed, during the early years of the new century, such was the growth within the secondary sector that it was putting more young people through GCSE Irish than the Catholic Grammar schools (Table 3).

\begin{tabular}{|c|c|c|}
\hline & Grammar & Non-Grammar \\
\hline 2000 & 1,144 & 1,308 \\
\hline 2001 & 1,226 & 1,444 \\
\hline 2002 & 1,264 & 1,425 \\
\hline 2003 & 1,210 & 1,320 \\
\hline 2004 & 1,060 & 1,188 \\
\hline
\end{tabular}

Although no single element can help to explain this growth, it is important to contextualise it within the rapid expansion of the Irish-medium

Table 3: Numbers studying GCSE Irish in Grammar and Non- primary education sector that had been Grammar Schools

actively promoted by republicans since the early 1980s. Throughout the 1990s the numbers attending such schools had increased rapidly from 675 in 1993 to 1,115 students in 1999 . By the $2006 / 07$ academic year the figure was over two thousand.

These rising numbers of young people educated primarily through the medium of Irish until the age of eleven greatly affected the secondary/non-grammar sector. There was now an onus on secondary schools to increase access to the language in a way that had not been prioritised previously. Moreover, given the level of Irish already acquired in these primary schools the obvious scenario was that students would be well placed to complete a GCSE in the language.

The overall rise in the numbers of young people studying Irish during this period, particularly those from working class communities, corresponds to the political emphasis placed on the language by Sinn Féin as it became the biggest nationalist party in Northern Ireland (Adams, 2005; Bew, 2009). The great challenge faced by the party - and all those seeking to promote the language - was maintaining this momentum as the peace process became more deeply embedded, and as a measure of political 'normality' came to prevail. With the creation of a more stable, peaceful, society there was a very real danger that the priorities of the population could, eventually, be directed away from the 'national question' towards issues around 
individual progress and social mobility (Breen, 2000). Indeed, there is growing evidence to suggest that this process is underway, with the constitutional question becoming less important and the 'Nationalist' community becoming increasingly satisfied with the new political dispensation (Hayward, et al., 2014). Findings from the longitudinal 'Northern Ireland Life and Times Survey', for example, have shown a decline in support for Irish Unity

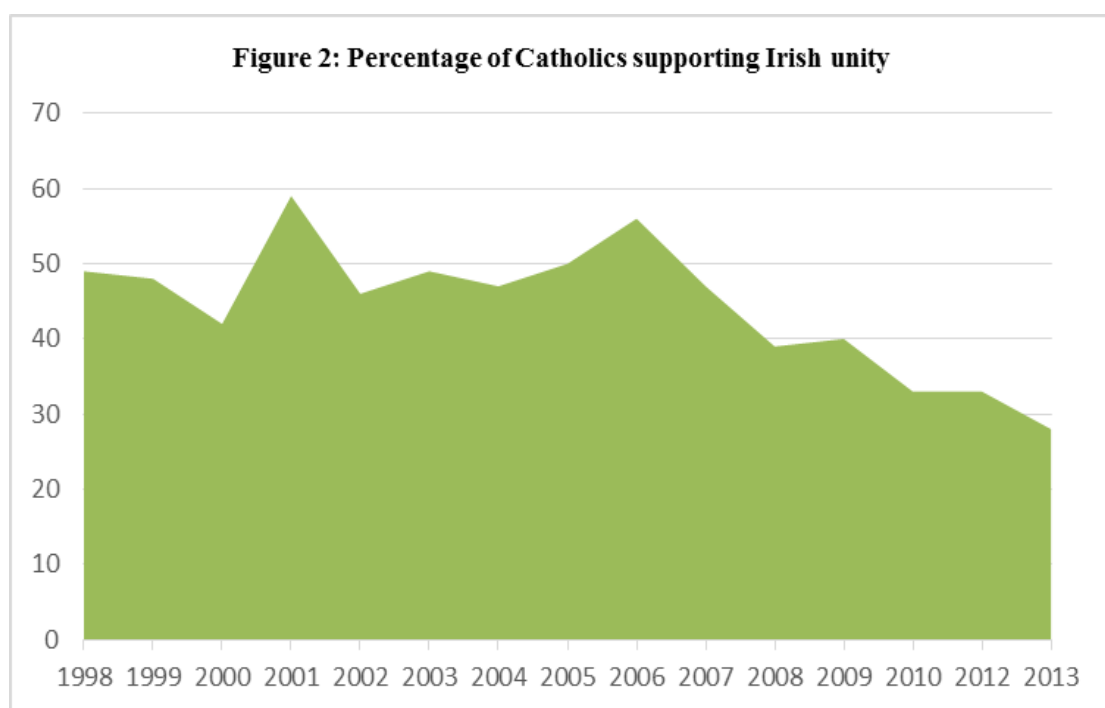

within the Catholic population between 1998 and 2010 despite the growing political support for Sinn Féin during that same period (Figure 2).

Data from the survey also suggests that, although

'Nationalist' continues to be the preferred political label, there is a growing number of people within the Catholic population that now consider themselves neither 'Nationalist' or 'Unionist' (Figure 3).

The nature of this 'normalisation' can also be assessed by examining how it has affected the study of the Irish language at GCSE level. Whilst numbers had increased as the political climate underwent significant change during the 1990 s and early 2000s, this has Figure 3: Catholics claiming to be 'Nationalist' and 'Neither Nationalist or Unionist'

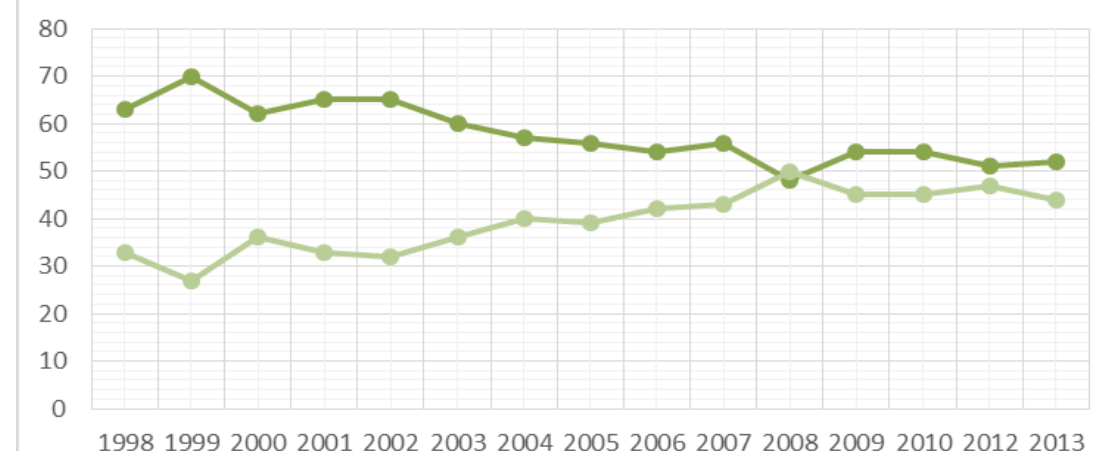
199819992000200120022003200420052006200720082009201020122013 $\longrightarrow$ Nationalist $\longrightarrow$ Neither altered dramatically over the past decade. From a peak of 2,689 students in the 2002 
academic year, the numbers had fallen to 2,248 by the 2004 term and, despite a temporary rise in $2006(2,446$ students $)$, by the 2011 term the figure sat at just 1,572 students. One of the most important features of this decline is that it has been almost exclusively within the Catholic secondary school sector (Figure 4). By the 2008 school year, only 661 students were

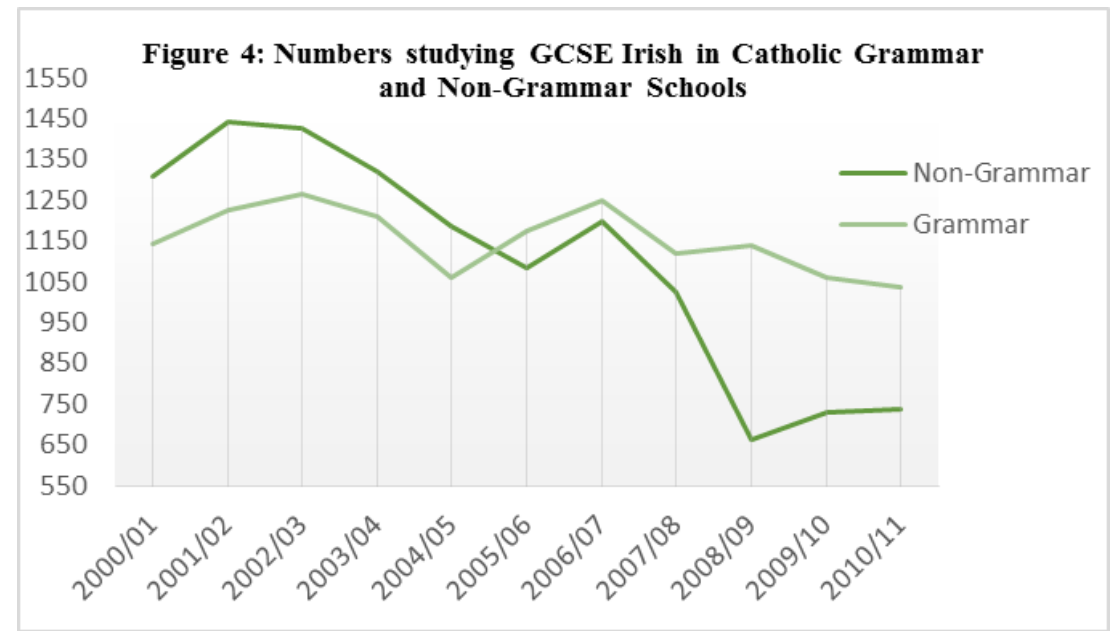
studying GCSE Irish within the non-grammar sector. This decline is explained, in part, by a significant broadening of the curriculum since 2007 , allowing for a much wider choice of subjects at GCSE level. It has been suggested that this, alongside the increased pressure on schools to achieve better GCSE results, has made the language less attractive for both students and schools, as one teacher explained:

I think they (schools) are shirking their responsibilities. Personally, I think that...it (Irish) is seen as a difficult option, and we are currently motivated by the results of league tables and if your subject produces results which aren't as positive then another subject is brought in which produces better results. ${ }^{13}$

This statement points to important changes that have taken place within the Catholic education system since the 1990s. In the first instance, there has been improved relations between the Catholic sector and the Westminster government so that the schools themselves feel better treated within the system and state (Osborne, et al., 1993). Furthermore, in line with the educational agenda pursued by Westminster governments since the 1980s (Tomlinson, 2005), the focus of the schools has shifted to meeting the demands for improved educational standards to aid economic priorities. These changes have, in the main, been 
welcomed, and reflect rising ambitions within large sections of the Catholic/Nationalist population as new job opportunities became available (Breen, 2000). Of the 534 Catholics that contributed to the Young Life and Times survey ${ }^{14}$ in 2013 , for example, 59 per cent believed they would be 'Going to college or university full time' in October 2015 whilst a further 31 per cent believed they would be 'At college or university and working part time'. That 90 per cent of the sixteen-year-old Catholics surveyed aspire to further their study gives an indication of the type of ambition for social and economic progress that seems to exist within large sections of that community which, potentially, could have implications for Irish nationalism in the years ahead.

\section{Conclusion}

Since the late 1960s nationalism has been identified as a dominant force in the political culture of Northern Ireland (English, 2006). This has taken on many of the characteristics of previous nationalist movements in Ireland including the cultural nationalism that characterised the early twentieth century and which sought, primarily, to protect and promote the Irish language as the national language (Crowley, 2008; Hutchinson, 1987; McMahon, 2008).

In placing the Northern Ireland situation within the theoretical framework of nationalism however, particularly the ethno-symbolist interpretation, this paper has argued that the relationship between the wider 'national' population and the cultural ideals of 'nationalist' leaders is hugely complex. Whilst political support for nationalist parties, particularly Sinn Féin, has increased since the 1990s, this has not led to a dramatic Irish language revival. Indeed, the party's significant efforts to promote its usage have achieved only limited success. 
Historically this failure has been caused, in part, by educational inequalities that have ensured notions of national identity became unevenly spread, with those gaining a more 'academic' education increasingly likely to have studied, at a higher level, those subjects deemed 'national'. That notions of national identity vary, based on educational attainment (and thus social class), has ensured that nationalism manifests itself in different ways across the population with certain ethno-symbols coming to mean more to a select few than they do to the wider population.

Finally, however, it has also been argued that recent educational reforms, concentrating on broader educational standards, have undermined the socialising dimension of schools when it comes to the politics of Irish nationalism. Consequently, the symbolism of the Irish language, even to those within more academic institutions, may further decline in the years ahead, reflecting the patterns of the Irish Republic since independence in 1922.

\section{Notes}

${ }^{1}$ I have chosen to look at language ahead of other 'ethno-symbols' primarily because it has been such an important theme in the history of modern Irish nationalism. The importance of other symbols tend to fall and rise in significance but the symbolism of Irish remains relatively consistent (Crowley, 2008).

2 Thomas Davis, 'Language and Nation' in The Nation, 1 April 1843

${ }^{3}$ The term Gaelic was previously the official term when referring to Irish. Today, the latter tends to be favoured.

${ }^{4}$ John Hume 'The Northern Catholic I' printed in the Irish Times 18 May 1964

${ }^{5}$ Academic examination taken at the age of sixteen.

${ }^{6}$ Voluntary sector in Northern Ireland are predominantly schools run by or under the auspices of the Catholic

Church who wanted to ensure maximum control of the educational provision afforded to Catholics. Compromises with the Unionist government meant that by the 1950s the government was meeting 65 per cent of capital and general costs but the remaining 35 per cent continued to be a significant problem for the schools.

${ }^{7}$ Interview with the author $12 / 12 / 2011$ 
${ }^{8}$ Ibid

${ }^{9}$ Ibid

10 'Jailtacht' is a play on the Irish word Gaeltacht that describes an area in which Irish is the primary language of the people.

${ }^{11}$ Linenhall Library Posters Collection, PPO 0191

12 These efforts often generated opposition from other Irish language groups who claimed that Sinn Féin were politicising the language. There was also some opposition from the Catholic Church towards the Irish language schools as they were in competition with Church run schools.

${ }^{13}$ Irish language teacher based in West Belfast. Interview with author 16/05/2011

${ }^{14}$ Participants, since 2003, have been 16 years of age. 


\section{References}

Adams, G., 1994. Free Ireland: Towards a Lasting Peace. Colorado: Roberts Rinehart Publishers.

Adams, G., 2005. The New Ireland: A Vision for the Future. Dingle: Brandon.

Anderson, B., 1991. Imagined Communities. London: Verso.

Anderson, B., 2012 [1996]. Introduction. In: G. Balakrishnan, ed. Mapping the Nation. London: Verso, pp. 1-16.

Armstrong, J. A., 1982. Nations before Nationalism. Chapel Hill: University of North Carolina Press.

Arthur, P., 1974. The People's Democracy, 1968-73. Belfast: Blackstaff Press.

Arthur, P. \& Jeffery, K., 1988. Northern Ireland since 1968. Oxford: Blackwell.

Atkinson, N., 1969. Irish Education: a History of Educational Institutions. Dublin: Allen Figgis.

Ball, S. J., 2008. The Education Debate. Bristol: Policy Press.

Barbour, S., 2000. Nationalism, Language, Europe. In: S. Barbour \& C. Carmichael, eds. Language and Nationalism in Europe. Oxford: Oxford University Press, pp. 1-17.

Barbour, S. \& Carmichael, C., 2000. Language and Nationalism in Europe. Oxford: Oxford University Press.

Bew, P., 2009. Ireland: The Politics of Enmity 1789-2006. Oxford: Oxford University Press.

Billig, M., 1995. Banal Nationalism. London: SAGE.

Boyce, D., 1995. Nationalism in Ireland. London: Routledge. 
Breen, R., 2000. Class Inequality and Social Mobility in Northern Ireland, 1973-1996. American Sociological Review, 65(3), pp. 392-406.

Brown, T., 2004. Ireland: A Social and Cultural History, 1922-2002. London: Harper Perennial.

Cannadine, D., 2000. Class in Britain. London: Penguin.

Cochrane, F., 1999. The Past in the Present. In: P. Mitchell \& R. Wilford, eds. Politics in Northern Ireland. Oxford: Westview Press, pp. 1-28.

Coenders, M. \& Scheepers, P., 2003. The Effect of Education on Nationalism and Ethnic Exclusionism: An International Comparison. Political Psychology, Vol 24, No 2, Special Issue: National Identity in Europe, pp. 313-343.

Collins, M., 1996. The Path to Irish Freedom. 2nd ed. Cork: Mercier Press.

Crowley, T., 2008. Wars of Words: The Politics of Language in Ireland 1737-2004. Oxford: Oxford University Press.

Davis, T., 1843. Our National Language. s.l.:s.n.

Devlin, B., 1969. The Price of my Soul. London: Pan Books.

Edwards, J., 2009. Language and Identity. Cambridge: Cambridge University Press.

English, R., 2004. Armed Struggle - The History of the IRA. London: Pan Books.

English, R., 2006. Irish Freedom: The History of Nationalism in Ireland. London: Macmillan.

Farren, S., 1995. The Politics of Irish Education, 1920-65. Belfast: Institute of Irish Studies.

Feeney, B., 2002. Sinn Féin: A Hundred Turbulent Years. Dublin: The O'Brien Press. 
Gellner, E., 1964. Thought and Change. London: Weidenfeld and Nicholson.

Gellner, E., 2006. Nations and Nationalism. 2nd ed. Oxford: Blackwell.

Goldstrum, J., 1977. The content of education and the socialization of the working-class child 1830-1860. In: Popular education and socialization int he nineteenth century. London: Methuen \& Co Ltd, pp. 93-110.

Gramsci, A., 2007. Selections from the Prison Notebooks. London: Lawrence and Wishart.

Green, A., 1990. Education and State Formation: The rise of education systems in England, France and the USA. London: Macmillan Press.

Hayward, K., Dowds, L. \& Shaw, C., 2014. Belonging and Alienation in the new Northern Ireland. Research Update, June.Volume 93.

Hjerm, M., 2001. Education, xenophobia and nationalism: a comparative analysis. Journal of Ethnic and Migration Studies, 27(1), pp. 37-60.

HMSO, 1998. The Agreement: Agreement Reached in Multi-Party Negotiations, Belfast: HMSO.

Hobsbawm, E., 1992. Nations and Nationalism since 1780. Cambridge: Cambridge University Press.

Howe, S., 2000. Ireland and Empire: Colonial Legacies in Irish History and Culture. Oxford: Oxford University Press.

Hroch, M., 2000. Social Preconditions of National Revival in Europe. 2nd ed. New York: Columbia University Press.

Hutchinson, J., 1987. The Dynamics of Cultural Nationalism. London: Allen \& Unwin.

Hutchinson, J., 2005. Nations as Zones of Conflict. London: Sage. 
Kamusella, T., 2012. The Politics of Language and Nationalism in Modern Central Europe. Basingstoke: Palgrave macmillan.

Keating, A., 2009. Educating Europe's citizens: moving from national to post-national models of educating for European citizenship. Citizenship Studies, 13(2), pp. 135-151.

Kelly, A., 2002. Compulsory Irish: Language and Education in Ireland 1870s-1970s. Dublin: Irish Academic Press.

Lawrence, P., 2005. Nationalism: history and theory. Harlow: Pearson Education Limited.

Lougheed, K., 2012. National education and empire: Ireland and the geography of the national education system. In: D. Dickson, J. Pyz \& C. Shepard, eds. Irish Classrooms and British Empire: Imperial contexts in the origins of modern education. Dublin: Four Courts Press, pp. 5-17.

Lyons, F., 1985. Ireland Since the Famine. London: Fontana Press.

MacIonnrachtaigh, F., 2013. Language, Resistance and Revival: Republican Prisoners and the Irish Language in the North of Ireland. London: Pluto Press.

Mallie, E. \& McKittrick, D., 2002. Endgame in Ireland. London: Coronet Books/Hodder \& Stoughton.

McCann, P., 1977. Popular Education, socialization and social control: Spitalfields 18121824. In: Popular education and socialization in the nineteenth century. London: Methuen \& Co Ltd, pp. 1-40.

McGrath, M., 2000. The Catholic Church and Catholic Schools in Northern Ireland - The Price of faith. Dublin: Irish Academic Press. 
McMahon, T., 2008. Grand Opportunity: The Gaelic Revival and Irish Society 1893-1910. New York: Syracuse University Press.

Ó hAdhmaill, F., 1989. Irish and the new educational reforms. British Journal of Educational Studies, Vol.37, No.1, pp. 72-77.

Ó Maolchraoibhe, P., 1986. The role of the language in Ireland's cultural revival. In: The role of the language in Ireland's cultural revival. Belfast: Sinn Féin, pp. 1-10.

O'Callaghan, J., 2009. Teaching Irish Independence: History in Irish Schools, 1922-72. Newcastle upon Tyne: Cambridge Scholars Publishing.

O'Mahony, P. \& Delanty, G., 2001. Rethinking Irish History: Nationalism, Identity and Ideology. Basingstoke: Palgrave.

O'Reilly, C., 1997. Nationalists and the Irish Language in Northern Ireland: Competing Perspectives. In: The Irish Language in Northern Ireland. Belfast: Ultact Trust, pp. 95-130.

O'Reilly, C., 1999. The Irish Language in Northern Ireland: The Politics of Culture and Identity. Basingstoke: Macmillan Press.

Osborne, R., Cormack, R. \& Gallagher, A., 1993. After the Reforms: Education and Policy in Northern Ireland. Aldershot: Avebury.

Phoenix, E., 1994. Northern Nationalism: Nationalist Politics, Partition and the Catholic Minority in Northern Ireland, 1890-1940. Belfast: Ulster Historical Foundation.

Pritchard, R., 1982. Modern Language Teaching in Northern Ireland. Teangeolas, 14, pp. 611.

Reisner, E. H., 1922. Nationalism and Education since 1789; a social and political history of modern education. New York: MacMillan Company. 
Sinn Féin, 1985. Learning Irish: A Discussion and Information Booklet. Belfast: Sinn Féin .

Sinn Féin, 1986. The role of the language in Ireland's cultural revival. Belfast: Sinn Féin.

Sinn Féin, 1987. A Scenario for Peace. [Online]

Available at: $\quad \underline{\text { http://www.sinnfein.ie/contents/15210 }}$

[Accessed 10 February 2012].

Smith, A. D., 2008. The Cultural Foundations of Nations: Hierarchy, Covenant, and Republic. Oxford: Blackwell Publishing.

Smith, A. D., 2009. Ethno-Symbolism and Nationalism, A Cultural Approach. London: Routledge.

Staunton, E., 2001. The Nationalists of Northern Ireland, 1918-1973. Blackrock: Columba Press.

Sweeney, K., 1988. The Irish Language in Northern Ireland: Preliminary Report of a Survey of Knowledge, Interest and Ability, Belfast: Policy, Planning and Research Unit.

Taylor, P., 1998. Provos: The IRA and Sinn Féin. London: Bloomsbury Publishing PLC.

Thompson, E., 2013. The Making of the English Working Class. London: Penguin.

Tomlinson, S., 2005. Education in a Post-welfare Society. 2nd ed. Maidenhead: Open University Press.

Wodak, R., de Cillia, R., Reisigl, M. \& Liebhart, K., 2009. The discursive construction of national identity. 2nd ed. Edinburgh: Edinburgh University Press.

Özkirimli, U., 2003. The nation as an artichoke? A critique of ethnosymbolist interpretations of nationalism. Nations and Nationalism, 9(3), pp. 339-355. 
Özkirimli, U., 2008. The Double Life of John Hutchinson or Bringing Ethno-Symbolism and Postmodernism Together. Nations and Nationalism, 14(1), pp. 4-9. 